MATEC Web of Conferences 19, 01040 (2014)

DOI: $10.1051 /$ matecconf/ 20141901040

(C) Owned by the authors, published by EDP Sciences, 2014

\title{
Mathematical model of traction electric drive for mine electric train
}

\author{
S.N. Kladiev, B.I. Pyakillya, A.D. Vilnin \\ National Research Tomsk Polytechnic University, 634050 Tomsk, Russia
}

\begin{abstract}
In this paper a mathematical description of a traction electric motor for a mine electric locomotive which takes into account skidding effect as a difference between linear speeds of wheel pairs and linear speed of locomotive is proposed. Obtained mathematical description enables to synthesize the PI-control which compensates the skidding effect and gives ability to carry out an optimal motion. This control scheme is implemented by means of low pass filter, band-pass filter and absolute value calculator.
\end{abstract}

\section{Introduction}

The skidding problem of vehicle motion, in our case the problem of mine electric locomotive motion, has a big practical importance. Solution of the problem helps to get optimal energy consumption and to reduce the locomotive acceleration time. First of all, skidding's conditions had to be determined. The skidding is a difference between linear locomotive speed and wheel pair speed. The complexity of the problem is due to inability of direct linear speed measurement because of mine's operative conditions. Therefore method of skidding indirect determination has been proposed by means of special filtration technique. Further the proposed method of determination will be considered in detail.

\section{Method of slipping speed reduce}

In skidding problem solution the computer simulation based on the mathematical model [1] has been used. Main dynamic properties of electric locomotive have been taken into consideration. The skidding compensation method for a first wheel pair will be considered, the second wheel pair is considered only in locomotive linear speed calculation, i.e. its influence on the locomotive dynamics is taken into consideration. Because of inability of direct torque measurement, an indirect torque measurement unit is introduced into computer model, which is described in terms of:

where $M_{\mathrm{r}}(t)$ is reference torque,

$$
M_{1}(t)=M_{\mathrm{r}}(t)+A \sin (\omega t)-J_{1} \varepsilon(t)
$$

$J_{1}$ is moment of inertia of first wheel pair,

$\varepsilon(t)$ is wheel angular acceleration,

$A$ is magnitude of harmonic searching signal,

$\omega$ is harmonic signal frequency.

The value of friction torque will be used for skidding effect determination. The choice of harmonic signal magnitude and frequency depends on electric machine properties, which is used in locomotive, also on the load of locomotive composition. The properties of harmonic signal have to be related with passband frequency of electric machine.

On the above, the slipping velocity, which causes the skidding effect, will be given by:

$$
U_{1}(t)=\left(\int_{0}^{t} M_{\mathrm{r}}(\tau)+A \sin (\omega \tau)-M_{1}(\tau) d \tau\right) \frac{R}{J_{1}}-V_{\mathrm{ml}}(t)
$$

where $\mathrm{R}$ is wheel radius, $V_{\mathrm{ml}}(t)$ is mine electric locomotive speed.

Torque of the first wheel pair, which depends on slipping velocity $[2,6]$, is given in terms of formula:

$$
M_{1}(t)=M_{\mathrm{r}}(t)-J_{1} \varepsilon(t)=\left(\Phi_{0}\left(1-\exp \left(\frac{-2 U_{1}(t)}{U_{0}}\right)\right) \frac{m R}{k_{\mathrm{r}}},\right.
$$

where $\Phi_{0}$ is clutch coefficient, $m$ is locomotive mass, $k_{\mathrm{r}}$ is reducer gear coefficient.

For slipping detection a combination of filters and calculated electromagnetic torque are used. This combination consists of serial connection of passband filter with transfer function

$$
W_{\mathrm{pf}}(p)=\frac{k p}{p^{2}+a p+b}
$$

and lowpass filter with transfer function in terms of

$$
W_{\mathrm{lpf}}(p)=\frac{1}{\frac{1}{\omega_{c}} p+1},
$$


where cutoff frequency $\omega_{c}$ is chosen in such way that all high frequencies caused by differentiation operation are eliminated. In the filtration technique an absolute value calculation unit, which simplifies analysis of obtained signal, is used. This technique enables to get the component, which depends on skidding effect. This component is used for compensation signal given by:

$$
U(t)=k_{i} \int e(t) d t+k_{p} e(t)
$$

where $k_{i}$ is integral gain,

$k_{p}$ is proportional gain,

$e=f(t)-f_{d}$, where $f(t)$ is output signal of filtration technique, $f_{d}$ is desired value of $f(t)$.

The gains $k_{i}, k_{p}$ are chosen by means of standard methods for PI controller. The desired value of filters output was chosen from computer simulation and equals to 0,4 . When value of filters output is bigger than $f_{d}$, then skidding starts, otherwise skidding doesn't exist.

The obtained control signal is used to compensate dynamic torque of electric machine[4,5],

$$
M_{e}=M_{\mathrm{d}}(t)+A \sin (\omega t)-U(t)
$$

which helps to decrease electric machine dynamic torque and reduce the slipping speed.

\section{Computer simulation results}

The computer model is based on the data of mine electric locomotive with parameters listed in Table 1.

TABLE I. MINE ELECTRIC LOCOMOTIVE PARAMETERS

\begin{tabular}{|l|c|}
\hline $\begin{array}{l}\text { Moment of inertia of } \\
\text { motor, } \mathrm{kg} \cdot \mathrm{m}\end{array}$ & 0,89 \\
\hline Wheel radius, $\mathrm{m}$ & 0,34 \\
\hline Reducer gear ratio & 14,2 \\
\hline Locomotive mass, kg & 14000 \\
\hline $\begin{array}{l}\text { Locomotive mass with } \\
\text { composition, kg }\end{array}$ & 10000 \\
\hline Wagon length, m & 4 \\
\hline
\end{tabular}

Further the characteristics of big importance for research are shown. All characteristics show the behavior of the system when skidding effect is happened.

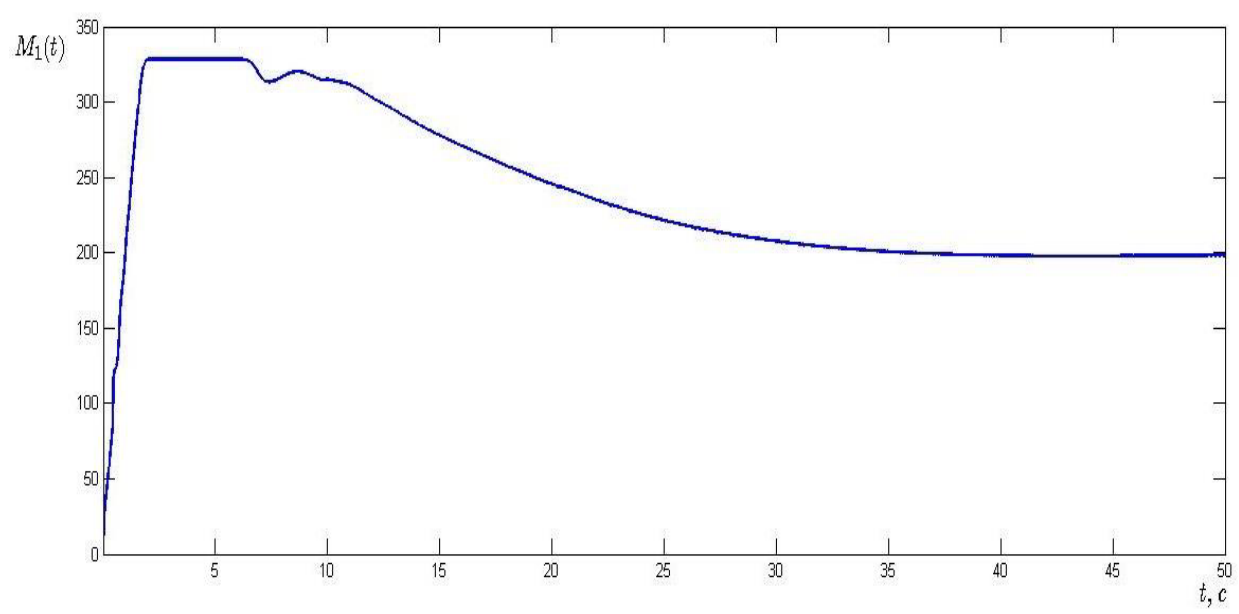

Figure 1. Friction torque of wheel pair 
From the characteristics may be seen that skidding effect is compensated by the proposed method. The filtration scheme output doesn't go away from desired value $f_{d}$.

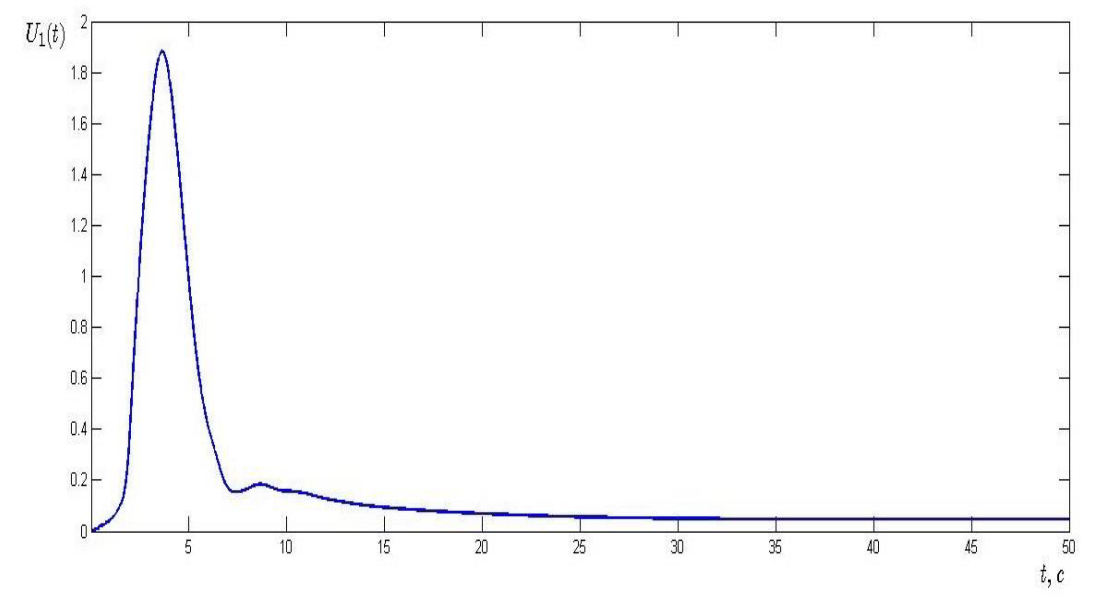

Figure 2. Slipping speed value for first wheel pair

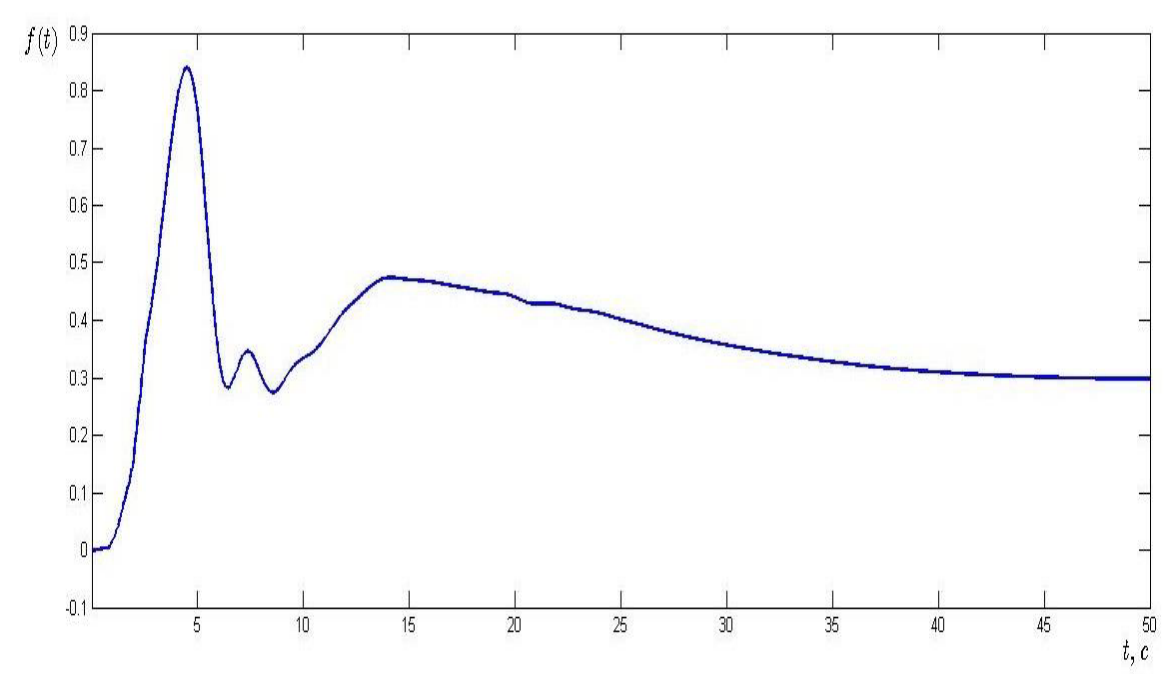

Figure 3. Filters output

From the above figures may be seen that skidding effect is compensated by the proposed method. The filtration output is equal to desired value $f_{d}$.

\section{Conclusions}

In this paper was described the skidding compensation method based on indirect skidding effect determination by means of special filtration technique. By means of obtained information the control system with PI controller was developed. The computer simulation experiments confirm the operability of the method.

The reported study was supported by the Grant «Nauka» 2.1318.2014.

\section{References}

[1] S. N. Kladiev, A.D. Vil'nin, B.I. Pjakillja. Model' jelektromehanicheskoj sistemy podvizhnogo sostava rudnichnogo jelektrovoza//Sovremennye tehnologii. Sistemnyj analiz. Modelirovanie. Vol. 1(37). Irkutsk: IrGUPS. 2013. pp. 65-68. (In Russian)

[2] A. D. Vil'nin, S. N. Kladiev, B. I. Pjakillja. Metod obnaruzhenija javlenija buksovanija v tjagovom jelektrovoze // Sovremennye tehnologii. Sistemnyj analiz. Modelirovanie. Vol. 3 (39). Irkutsk:IrGUPS. 2013. pp. 264-266. (In Russian)

[3] A. D. Vilnin, S. N. Kladiev, B. I. Pyakillya, "Detection device of slipping and skidding wheelpair mine locomotive traction” RU Patent 141267, May 27, 2014

[4] P. Tipler, "Physics for Scientists and Engineers: Mechanics, Oscillations and Waves, Thermodynamics (5th ed.)". W. H. Freeman,2004.

[5] Timoshhenko A.V., "Dinamika avtomatizirovannogo jelektroprivoda rudnichnogo jelektrovoza s cifrovym ustrojstvom raspoznavanija buksovanija" // Elektrotehnichni ta komp'juterni sistemi. Vol. 03(79) Odessa: Odessa National Polytechnic University. pp. 153-154 (In Ukrainian)

[6] Ju.N. Kutovoj, "Povyshenie tjagovyh svojstv rudnichnogo jelektrovoza sred-stvami jelektroprivoda": PhD thesis, Kharkiv, 1984. - 186 pp. (In Russian) 